\title{
To live and let die: Food, famine, and administrative violence in Democratic Kampuchea, 1975-1979
}

\author{
James A. Tyner*, Stian Rice \\ Department of Geography, Kent State University, Kent, $\mathrm{OH} 44242$, USA
}

\section{A R T I C L E I N F O}

\section{Article history:}

Available online 14 June 2015

\section{Keywords:}

Violence

Genocide

Famine

Cambodia

\begin{abstract}
A B S T R A C T
Between 1975 and 1979 approximately two million people died in the Cambodian genocide. We argue that the mass violence that transpired during this period was a manifestation of the Khmer Rouge's attempt to make life. Through a focus on the production of both violence and vulnerability we direct attention to the contradictory policies and practices forwarded by the Khmer Rouge that were designed to maximize life through the maximization of death. Specifically, we consider the mass starvation that accompanied the genocide as a structure of violence; we forward the argument that the rationing of food constitutes a calculated yet contradictory policy, namely that food rations represent in material form an inner contradiction of fostering life and disallowing life. Subsequently, the policy of forced ration$\mathrm{s}$ - which imposed a particular space of vulnerability on Cambodia's population-resulted in massive loss of life through starvation and disease that were not the unintended side-effects of poor research, poor planning, or poor implementation on behalf of the Khmer Rouge, but rather were the necessary consequences of a proto-capitalist form of state-building.
\end{abstract}

(C) 2015 Elsevier Ltd. All rights reserved.

\section{Introduction}

The Communist Party of Kampuchea (CPK; also known as the 'Khmer Rouge') constitutes one of the most violent and inhumane apparatus of state terror in the twentieth-century. Between April 1975 and January 1979 the Khmer Rouge carried out a program of mass violence that is, in many respects, unparalleled in modern history. In just under four years, approximately two million people died from starvation, disease, exhaustion, inadequate medical care, torture, murder, and execution. The total number of deaths translates into one-quarter to one-third of the country's pre-1975 population (Heuveline, 1998; Kiernan, 2003).

What accounts for the systemic and systematic violence that gripped Cambodia? How are we to conceive of the active 'taking' of life and of the 'disallowal' of life of so many people in such a short span of time? Conventional accounts of the Cambodian genocide focus on the destructive practices initiated by the Khmer Rouge: the brutal evacuation of all towns and cities; the forced relocation of people into communes and work-camps; the abolition of currency and private property; and the targeted execution of doctors, teachers, engineers, and multiple other 'classes' of people that did

\footnotetext{
* Corresponding author.

E-mail address: jtyner@kent.edu (J.A. Tyner).
}

not belong to the planned utopia envisioned by the Khmer Rouge. Most accounts highlight also the rhetoric of the Khmer Rouge-that Democratic Kampuchea, as the country was renamed, was to become an autonomous, self-sufficient state free from foreign domination.

These accounts provide only half the story. Yes, the Khmer Rouge upon assuming power (in fact, even before) embarked upon a massive, destructive policy of eradication. However, what is less appreciated is that the Khmer Rouge intended to build an entirely new state and society. And while the Khmer Rouge actively destroyed the existing societal infrastructure-health, education, commerce, religion, and family - they also planned to replace these with their own infrastructure. The Khmer Rouge for example proposed-if not fully implemented-an assemblage of biopolitical practices that addressed the management of marriages, births, and fertility at the level of the population. These practices included, but were not limited to, forced marriages and the allocation of increased food rations for pregnant or nursing women, both to facilitate reproduction. Moreover, a system of 'care centers' for infants, children, the aged, and disabled was proposed. Accordingly, child-care centers were to be established in co-operatives, factories, offices, ministries and even military units; within these centers children would be educated and taught the means necessary to increase production according to the concrete situations in which they resided. 
In short, practices in Cambodia that we now designate as 'genocidal' were in fact practices of state-building and, ironically, life-making. Therein lays the crux of our paper: the mass violence-and death-associated with the CPK leadership was a manifestation of their attempt to make life. Such a statement is not to absolve the Khmer Rouge of responsibility; nor is it to diminish the brutality of Khmer Rouge practice. Rather, it is to direct attention to the contradictory policies and practices forwarded by the CPK that were designed to maximize life through the neglect of (selected) lives. Recognition of such contradictions may better enable us to understand the coordinates of the Cambodian genocide; to articulate more precisely the calculated management of life and death that underscored the genocide; and to more effectively argue that famine-related deaths should be prosecuted as crimes against humanity (cf. DeFalco, 2011, 2013a, 2013b).

In this paper we consider mass starvation as a structure of violence. Specifically, we forward the argument that the rationing of food, as intentionally imposed and administered by the CPK, constitutes a calculated yet contradictory practice-a practice that signifies the overall attitude toward life and death during the genocide. Specifically, the food ration represents, in material form, the inner contradictions of fostering life and disallowing life. It is, in other words, a unity of opposites, for on the one hand it provides nourishment and sustenance while, on the other hand, it acknowledges its own limitations. Achille Mbembe writes of biopower: "To exercise sovereignty is to exercise control over mortality and to define life as the deployment and manifestation of power" (2003: 12). As the technology by which death comes to be regulated, the ration is established as a material expression of state sovereignty: it literally makes the living as it makes the dead.

The starvation that marked Democratic Kampuchea, accordingly, was viewed by members of the CPK not as a famine-but rather as a technical problem stemming from aberrant causes-including the failure of inept or traitorous low-level cadre. For the CPK elite, there could be no scarcity of food because the population was producing a surplus. And while any given individual might endure periods of hunger, these could not be viewed as a condemnation of state-practice, for the state was actively-indeed, aggressively-implementing policies designed to foster life. Indeed, when CPK leaders were confronted with reports of famine, they blamed these problems on 'internal enemies' or from mistakes of local officials in implementing CPK policy (DeFalco, 2011: 147).

This paper is organized into seven sections. We begin by reviewing recent geographic writing on administrative violence and challenge the distinction between killing and letting die. In Sections 2 and 3, we supplement these notions with concepts developed in the literature on famine and vulnerability. We propose that through administrative violence - vulnerability to mass starvation and disease is actively and intentionally produced. In Sections 4 and 5 , we explore the organization and consequences of agriculture, trade, and security policies under the Khmer Rouge, drawing comparisons between other historical and contemporary famine events. In Sections 6 and 7 we apply these examples to demonstrate how the CPK's transformation of Cambodia's "space of vulnerability" managed death in the name of managing life. It is this informed and intentional production that makes persuasive the argument for holding CPK policy-makers directly responsible for famine deaths, for it was precisely the design and implementation of such purposeful administrative violence that generated those conditions.

\section{Letting die as administrative violence}

Recent years have witnessed an upswing in the geographic writing-and theorizing —of violence (Loyd, 2009, 2012; Springer, 2008, 2009, 2011, 2012; Tyner, 2009, 2012a, 2014a; Tyner \&
Inwood, 2014). This work has, specifically, sought to deepen our understanding of violence; to critically question not simply the consequences or remembrances of violence, but also the 'act' or 'event' of violence. This is seen most notably in the recent work addressing the philosophical distinction between 'killing' and 'letting die' (cf. Anglin, 1998; Li, 2009)-a distinction that has tremendous bearing on our understanding of famine.

For many bioethicists and philosophers, the act of killing is considered to be morally worse than letting die. Such a presumption hinges on our understanding of agency: to 'kill' is considered an action whereas 'letting die' is perceived as an omission, or lack of action. This moral partition, likewise, is premised on a distinction between 'negative' and 'positive' duties. And while these differ by culture, in general we can identify the existence of duties not to harm others, which require restraint; these are termed negative duties. We also have positive duties whereupon we have duties (some might say, obligations) to help others.

The dichotomy between 'positive' and 'negative' duties, as well as between 'killing' and 'letting die' significantly inform international law and, specifically, the prospect of prosecuting states for human rights abuses. Simply put, international tribunals and warcrime trials focus attention on forms of direct, physical violence (i.e. extrajudicial executions, war-rape, and torture); these are actions for which both an 'individual' may be found guilty and where the intent was specifically to harm others. The failure to provide positive duties, such as adequate medical care or even food, is generally not viewed as a crime against humanity; this holds even if those 'inactions' lead to the death of hundreds of thousands of people.

For Galtung (1969) direct violence occurs when there is an identifiable actor who commits an act of violence. Structural violence, conversely, occurs when no such actor is identifiable. Galtung (1969, 170-71) elaborates that "whereas in the first case [direct violence] these consequences can be traced back to concrete persons or actors, in the second case this is no longer meaningful. There may not be any person who directly harms another person in the structure. The violence is built into the structure and shows up as unequal power and consequently unequal life chances" (emphasis added).

Galtung's conceptualization of structural violence has been influential but, as a whole, remains challenging. Indeed, Gupta (2012, p. 19) allows that structural violence, conceptually, is both necessary and problematic. In part, this consternation arises from Galtung's original focus on outcomes, rather than processes. Gupta (2012, p. 20) elaborates that for Galtung, violence was present when outcomes (or conditions of living) were unequal. Thus, structural violence is found when groups of people are denied access to food, water, and shelter; structural violence is also found whenever groups of people are excluded from particular forms of recognition and representation, including but not limited to citizenship rights, rights before the law, and rights to education (Gupta, 2012, 20).

However, lurking beneath a focus on unequal structures is a more difficult question: What role does 'intentionality' play in structural violence? As we have seen, direct violence is characterized by intentionality of an identifiable actor while structural violence appears as a 'crime without a criminal' (Gupta, 2012, 21). Intentionality, however, is a slippery concept for two reasons. First, to argue, morally, that a failure to act is intentional, one must satisfy three conditions: ability, opportunity, and awareness. Following Green (1980, p. 196), to fail to act involves not performing an action but having the ability to perform the action. Posed as a question, is an individual in a position to prevent a harm (or death) but, through his or her inaction, fails to do so? Second, there is the condition of opportunity. Does any particular individual have the opportunity to 
prevent harm? Last, there is the condition of awareness. Is one aware of the conditions that contribute to harm befalling another person? Applying these three conditions, let us return to the concept of 'structural' violence. As commonly employed, this concept is premised on the argument that certain inequalities are systemic; in other words, there is no individual to blame. However, when we recast structural violence within the context of letting die, we readily see that many individuals, such as politicians and corporate managers, in reverse order, (1) are aware of harmful policies and practices that might disallow life; (2) have the opportunity to stop or remedy these policies and practices; and (3) have the financial—or political-ability to prevent harm.

At this point, the distinction between 'killing' (as a form of direct violence) and 'letting die' (structural violence) begins to collapse. This move is strengthened by the recent work of feminists and social anthropologists who have further challenged the apparent dichotomy between these forms of violence (Anglin, 1998; Confortini, 2006; Hume, 2008; Tyner, 2012a). For these scholars, what superficially appears as a binary between two different and oppositional 'forms' of violence is in actuality a dialectics of violence. According to Ollman (2003: 12), "dialectics is a way of thinking that brings into focus the full range of changes and interactions that occur in the world." This is counter to more conventional and pervasive epistemologies-of which naïve empiricism is exemplary-that disaggregate the world into discrete and unrelated entities. This is seen, for example, in the tallying of deaths resultant from torture and execution as opposed to disease and starvation. Dialectics, conversely, opens space for a deeper and more profound analysis. Dialectics restructures our thinking and our ontological reality by replacing the commonsense notion of 'thing' with notions of 'process', 'relation', and 'change'. This allows us to both reconsider "how something works or happened while simultaneously developing [an] understanding of the system in which things could work or happen in just this way" (Ollman, 2003: 15).

The theoretical separation of 'direct' and 'structural' violence, while superficially helpful in working through various concrete acts, is an abstraction that limits our dialectical understanding of violence. Thus, what appears as a dichotomy between two different 'forms' of violence is actually not. What if we abstract differently? What if we refuse to abide by the separation of 'direct' and 'structural' forms? What if we abstract violence as any action or inaction that affects the material conditions of another, thereby reducing one's potentiality to survive? Through this process of abstraction, the separation between 'direct' and 'structural' violence, as well as the separation between 'killing' and 'letting die' collapses completely. As Graeber (2012) argues, 'structural violence' is often presumed to consist of structures that have violent effects: racism, sexism, patriarchy, and poverty for example. Thus, it is more appropriate to think of these as structures resulting from physical violence-or the threat of violence. In other words, structures of violence are supported through the use or threat of physical violence; likewise, structures of violence provide context for physical violence. In this paper, we apply this same logic to conditions of famine, malnutrition, and disease in the case of the Cambodian genocide, to demonstrate how the threat and actual use of force was a necessary condition for the continuance of these structures which ultimately 'let die' approximately one million men, women, and children (cf. Tyner, 2012b).

It is insufficient, however, to call for a dialectical relation between 'direct' and 'structural' violence without identifying a specific assembly. Here we follow recent work that has forwarded the concept of 'administrative' violence (Beaugrand, 2011; Gunneflo, 2012; Gupta, 2012; Spade, 2011; Tyner, 2014b). Conceptually, administrative violence originates in the early theorizing of
Benjamin (1921) who distinguished between 'law-making' and 'law-preserving' violence. The former-also understood as foundational violence - is associated with the moments of the investiture of law; the latter, conversely, constitutes an administrativelyenforced violence, as exemplified by the establishment of judicial and police apparatuses.

\section{The production of famine and vulnerability}

For centuries, the common view - famously articulated by Thomas Malthus - explained famine as a case of too many mouths and too little food (Malthus and Gilbert, 1993). In the prototypical case of subsistence famine, dramatic variations in climate wreaks havoc with simple agricultural systems, leading to food shortages across large areas. During the 19th century, governments and their critics began to acknowledge the role of social and political structures in the trajectory of famine (Nally, 2011), as evidenced by China's response to the Incredible Famine during the late 1870s (Edgerton-Tarpley, 2008) and the design of British India's famine codes in the 1880s (Rangasami, 1985). Despite this acknowledgment, throughout much of the 20th century, neo-Malthusian arguments persisted: famines may be exacerbated by people and institutions, but they are ultimately the devastating handiwork of a fickle Nature.

In the aftermath of the African food crises of the 1970s and 80s, political and economic structures became central to the discussion of famine causation. With publication of the conspicuously titled report "Famine: a Man-Made Disaster" (Brown, 1985), the Independent Commission on International Humanitarian Issues opened the door to a more critical examination of the institutional role in mass starvation. Meanwhile, Marxist correctives placed blame on exploitative capitalist structures operating at a variety of scales (for example, Franke \& Chasin, 1980; Meillassoux, 1974). Critically, these authors began to understand famine not only as socially produced, but intentionally produced, rewarding winners while others starved. Since then, scholars have found abundant fodder in the historical record, exposing the role colonial institutions, development programs, unfettered markets, and war played not just in the deepening and prolonging of mass starvation, but in its very creation (for examples, see ; Davis, 2002; Hionidou, 2006; Keen, 1994; Watts, 2013).

This move away from "meteorological and demographic explanations" (Watts, 1991: 9) towards an indictment of social structures and processes is exemplified in the work of Amartya Sen (1981) and Dreze and Sen (1991). Sen's entitlement-centered approach identified the salience of the relationship between people and commodities (in this case, food). For Sen, famines have little to do with how much food is available, and almost everything to do with the politics of food distribution. Since the early 1990s, critiques of Sen have suggested that his approach takes an overly-narrow focus on entitlements, to the exclusion of both environmental conditions and historical contexts (for example, Woo-Cumings, 2002; see also Essex, 2009, 2012). Watts and Bohle (1993) for example expand Sen's theory of famine to include both human-environment interactions and the broader political economy. Most relevant to our discussion, Watts and Bohle's paper contributes to a nowflourishing literature on vulnerability. As Bohle, Downing, and Watts (1994) explain, vulnerability to a food crisis can be calculated by way of three "coordinates": the risk of exposure to crisis, the risk of inadequate capacity to cope with crisis, and the risk of severe consequences. The overall vulnerability of a population can be said to grow with increasing exposure, decreasing capacity to cope, and increasing potential harm. Thus, societies in which high exposure is coupled with limited capacity and serious potential for harm are considered the most vulnerable. 
To understand what causes changes in vulnerability, Bohle et al. propose three modes of inquiry, each at a different scale and level of abstraction:

Human ecology - concerned with the interaction of humans and their immediate environment; for example, the relationship between tilling practices and topsoil quality.

Expanded entitlements - the totality of material and social resources available to people for the acquisition of food; for example, money, access to land, farming knowledge, and social networks of exchange.

Political economy - the macro-structures influencing the distribution and use of entitlements and resource endowments; for example, national and global regimes of accumulation and the crisis tendencies implicit therein.

To find the factors contributing to each coordinate of vulnerability we examine the intersections of these three overlapping modes of inquiry. Thus, to understand the causes of exposure, one looks to human ecology and expanded entitlements. To understand changes in capacity, one looks to expanded entitlements and political economy. To understand changes in potentiality, one looks to political economy and human ecology.

Stepping back, the space of vulnerability and its three-part expression describes famine as a consequence of conditions, each of which might be the symptom of processes (some political and some not), leading to disastrous consequences (some intended and some not). We wish to reiterate a more direct - though less comfortable - proposal, that vulnerability is not simply a consequence of diverse and myriad conditions, but is purposefully produced. We propose that control over exposure, capacity, and potentiality are part of an ongoing bio-political project with attendant winners and losers. As such, to read the contours of vulnerability in a society is to read the contours of power.

In so doing, we reaffirm Edkins' (2002: 17) observation that "famines are not caused by abstractions ... they are brought about through the acts or omissions of people or groups of people." For this reason, Edkins prefers the term "mass starvation" as a parallel to mass killing and genocide: "When we call something a famine it seems no one is to blame; it is only when we call it a genocide that we look for perpetrators" (Edkins, 2007: 51).

\section{The violent production of vulnerability}

Much of the scholarship on vulnerability has skirted questions of violence even as the atrocities of past famines have become the subject of extensive research. Indeed, one critique of the entitlement approach is its failure to address a myriad of extra-legal processes, from black markets and violent expropriation of food to physical and psychological coercion. Edkins writes: "Sen's approach ... excludes any adequate understanding of precisely those conditions that obtain whenever there is a famine - the denial of access to food by force employed on behalf of those who possess food" (Edkins, 2000: 59). Other scholarship has asked and attempted to answer the questions posed by Keen (1994: 12): "What use is famine, what functions does it assure, in what strategies is it integrated?" Rangasami's (1985) rejoinder to Sen describes famine as a protracted politico-social-economic process of oppression in which "benefits accrue to one section of the community while losses flow to the other" (1985: 1748).

Building on the work of Watts and Bohle, Edkins, and Rangasami, we seek to conceptually link vulnerability and violence. Vulnerability is expressed through increased exposure to crisis, reduced capacity to handle crisis, and greater likelihood of severe consequences (Bohle et al., 1994). Vulnerability is produced by individuals and institutions at a variety of scales for particular purposes. From our earlier definition, violence is any action or inaction that affects the material conditions of another, and in so doing, reduces one's potentiality to survive: or to put it another way, violence is any action or inaction that increases vulnerability. Thus, the production of vulnerability constitutes a violent act.

Subsequent sections explore the policies and practices of the $\mathrm{CPK}$, bringing into sharp relief the administrative production of violence and vulnerability. At an abstract level this exploration illuminates the dialectic relationship between direct and structural violence. More concretely, it follows the work of Randle DeFalco by furthering the argument for treating the Cambodian famine as a crime against humanity (2011, 2013a, 2013b). We continue DeFalco's efforts-but with one important corrective. Scholars of the Cambodian genocide have in general argued that the CPK "ignored the numerous difficulties" that would result from a tripling of rice production (cf. DeFalco, 2013a: 31). Chandler, Kiernan, and Boua (1988: 133) for example writes that "despite lip-service in texts and speeches to studying [Democratic] Kampuchea's 'objective conditions,' it is unlikely that much studying took place." Such an argument, we suggest, is both inaccurate and counter-productive to the objective of prosecuting senior leaders for crimes against humanity. The CPK did make-in their minds-rational calculations based on an analysis of objective conditions. Indeed it is this rational administration of agricultural policies that supports the argument that CPK leaders were aware of the growing vulnerability to mass starvation, and that the CPK had the ability and opportunity to remedy these policies-if it was in their own interest. That the CPK did not work to end the crisis, thereby disallowing life to millions of its citizens, is an extreme example of administrative violence. Moreover, the arrests, tortures, and executions of those who did complain or resist signify a form of law-preserving violence that was necessary to enforce the CPK's agricultural policies.

\section{Agricultural practices under the Khmer Rouge}

The CPK-based on an eclectic understanding of Marx, Lenin, and Mao-embarked upon a massive program of social engineering. In their attempt to remake Cambodia into a modern industrial state, the CPK launched a 'Super Great Leap Forward' that included the mass collectivization of labor and communal eating; forced marriages; the destruction of urban areas; the abolition of private property and currency; and the elimination of religion (Tyner, 2008). These practices were not part of an overall comprehensive design-indeed the Maoist-inspired 'Super Great Leap Forward' suggests more design than was present. Nor for that matter were most proposed policies ever put into practice. Those policies that did materialize, however, led to the death of approximately two million people.

As part of its overall goal of achieving autonomy and selfmastery, the CPK premised that success depended on agricultural productivity. As explained in its 'Four-Year Plan', developed between July 21 and August 2, 1976, the CPK identified two economic objectives. The first was "to serve the people's livelihood, and to raise the people's standard of living quickly, both in terms of supplies and in terms of other material goods" (Party Center, 1976b: 51). This was to be accomplished through the satisfaction of a second objective, namely to "seek, gather, save, and increase capital from agriculture, aiming to rapidly expand our agriculture, our industry, and our defense rapidly" (Party Center, 1976b: 51). Therefore, to achieve industrial self-sufficiency-including both light and heavy industry - the CPK decreed that they would "only have to earn [foreign] capital from agriculture" (Party Center, 1976b: 96). 
It is necessary at this point to consider more closely the evolving geography of Democratic Kampuchea's space-economy. Administratively, Democratic Kampuchea was partitioned into several zones (Phumipeak); in turn, zones were divided into regions (Damban), districts (Srok), sub-districts (Khum), co-operatives (Sahaka), and villages (Phum). The CPK's spatial organization of the country was pivotal for its administrative practices-including those related to agriculture. Each political sub-division (i.e. Zone, Region, District, Sub-District, and Co-operative) was governed by a three-person Committee consisting of a secretary, deputy secretary, and member. The Zone Committee, consequently, was responsible for overseeing the implementation of Party plans and policies throughout its respective Zone; and for delegating plans and policies to all other levels (e.g. Regions, Districts) in its Zone. Likewise, the committees at the Region, District, Sub-District, and Cooperative levels fulfilled similar functions of implementing tasks designated by the CPK upper echelon.

Each political sub-division was, in theory, to be self-reliant and autonomous. This practice conforms to the broader ideological thrust of the CPK. However, it was recognized by the CPK that no Zone, District, or other political unit could be entirely autonomous; some form of integration was necessary and may be viewed as one 'integrated autonomy'. Simply put, interactions (including the movement of information and commodities) were channeled hierarchically through the three-person committees; control was ultimately overseen by the CPK. Lower-level cadre, for example, those governing at the District level, were required to channel any requests to their immediate supervisors at the Region level; these cadre would, in turn, forward the request to the Zone level, where it would then be routed to the relevant offices of the CPK. There were to be no 'horizontal' relations; hence, a District commander could not request supplies from a neighboring District commander. He or she would have to route the request through the Zone before it would be re-routed to the other District cadre.

Returning to the twin objectives established by the CPK-the making of life through the generation of agricultural surplus-it becomes clear that policy decisions were based on particular productivity calculations. Foremost was the proposed increase in rice production-an objective that was pivotal to the CPK's overall strategy of state-building and-by extension, the state's ability to foster life in Democratic Kampuchea. This is vividly illustrated in a series of remarks prepared and delivered by Pol Pot to a special meeting of the CPK 'center' during August 21-23, 1976. Here, Pol Pot considers "the production of rice as it is related to rice fields." He explains:

We have greater resources than other countries in terms of rice fields. Furthermore, the strength of our rice fields is that we have more of them than others do. The strength of our agriculture is greater than that of other countries in this respect .... It is the Party's wish to transform agriculture from a backward type to a modern type in ten to fifteen years. A long-term strategy must be worked out. We are working (here) on a Four-Year Plan in order to set off in the direction of achieving this 10-15 year target (Party Center, 1976a: 131).

It was determined by the CPK that Democratic Kampuchea would need to triple rice productivity, to a national average yield of three tons per hectare per year. Only by attaining such a surplus could the CPK raise sufficient revenues to obtain necessary goods and commodities from abroad, notable among these was ammunition. The strategy for increased rice production was predicated on the introduction of more 'rational' and 'efficient' agricultural techniques. Thus, the CPK classified rice fields into two categories: those harvested once a year and those harvested twice. Calculations provided by the CPK indicate that in 1977 there would be an anticipated 2.4 million hectares of land suitable for rice production; of these, 1.4 million hectares could sustain a single harvest per year; the remaining would be conducive to two harvests. Over the next four years, according to Pol Pot, the land devoted to single harvests would remain constant, while the amount of double-cropped lands would progressively increase from 200,000 ha in 1977 to 500,000 in 1980. However, it was determined that all new agricultural lands would generate two harvests per year (Party Center, 1976a: 132).

Pol Pot and the CPK also identified a number of 'objective' problems related to the production of rice, including but not limited to the availability of water for irrigation, access to necessary fertilizers, pesticides and herbicides, and adequate numbers of agricultural tools. As to irrigation, the CPK launched massive work projects-employing forced labor-to construct a network of dikes, canals, and reservoirs. As for chemicals and tools, these were either to be manufactured within Democratic Kampuchea or purchased from abroad, again using revenues generated from the export of rice.

The collectivization of agriculture and establishment of forced labor camps was likewise crucial to the successful implementation of the CPK's rice production strategy. Cooperatives, ranging in size from several hundred people to several thousand, were established to cultivate specified crops, including rice but also vegetables, fruits and other non-food crops such as rubber, cotton, and jute. The collection and distribution of crops was centralized, with each cooperative chief responsible for meeting production quotas established by the Party Center.

\section{Food rations and relative surpluses}

The expansion of lands devoted to rice production, the attempt to overcome 'objective' problems, and the intensification of work all constituted efforts to generate absolute surpluses. To these material practices, however, the CPK added an exploitative practice that, in effect, was a means of attaining relative surpluses. Such a statement appears discordant with our knowledge of the Khmer Rouge as a communist revolution and thus requires some additional elaboration. Following Marx, when capitalists purchase laborpower-the capacity to work - they do so on two conditions: first, that the laborer works under the control of the capitalist to whom his or her labor belongs and, second, that the product is the property of the capitalist and not that of the worker (Marx, 1990: 291-292). In so doing, the capitalist is able to "produce a commodity greater in value than the sum of the values of the commodities used to produce it, namely the means of production and the labor-power he [sic] purchased with his good money on the open market" (Marx, 1990: 293). Therein lies the original source of surplus-value, in that "by incorporating living labor into their lifeless objectivity, the capitalist simultaneously transforms value, i.e., past labor in its objectified and lifeless form, into capital, value which can perform its own valorization process" (Marx, 1990: 302).

To clarify this process, Marx distinguishes between 'necessary labor time' and 'socially necessary labor time.' He explains that necessary labor time is that amount required to reproduce the laborer and his or her family; this is, as indicated above, the "value of labor-power' and is used to determine wages. Workers, for example, may produce enough value in $6 \mathrm{~h}$ to offset their reproduction. Capitalists, however, purchase labor-power for a full day's work, say, $10 \mathrm{~h}$. The remaining $4 \mathrm{~h}$, Marx argues, appear as absolute surplus labor time.

Marx argues that all value (including surplus value or profit) is created by labor, and that surplus value is brought about by the exploitation of direct or living labor (Saad and Filho, 2010: 34). Initially, greater profit may be derived from extending the working- 
day. Thus, if the labor-power purchased by the capitalist is $12 \mathrm{~h}$, rather than the aforementioned $10 \mathrm{~h}$, then an additional $2 \mathrm{~h}$ of surplus value are created. The prolongation of the working day, according to Marx (1990: 645), "forms the general foundation of the capitalist system."

There are, however, significant limits on the extent to which capitalism can depend on the production of absolute surplus value; the working day, for example, can only be extended so long. For Marx, therefore it was not 'necessary' labor time that was the root of labor-power's value; rather it was socially necessary labor time. Defined by Marx (1990: 129) as "the labor-time required to produce any use-value under the conditions of production normal for a given society and with the average degree of skilled and intensity of labor prevalent in that society," a consideration of socially necessary labor time transfers the level of argument from individual capitalist to society as a whole. This is possible because, as Fine and Saad-Filho (2010: 38) explain, "production of relative surplus value depends critically upon all capitalists, since none alone produces a significant proportion of the commodities required for the reproduction of the working class."

Simply put, an increase in average productivity increases the average number of commodities produced per unit of time; it thereby decreases the amount of socially necessary labor time required for the production of a single commodity and, hence, the value of each commodity (Postone, 1993: 193). With an increase in the productivity of labor-through refinements of the division of labor or the introduction of machinery-the value of labor-power falls and the portion of the working day necessary for the reproduction of that value will be shortened. Capital thus "has an immanent drive, and a constant tendency, towards increasing the productivity of labor, in order to cheapen commodities and, by cheapening commodities, to cheapen the worker himself" (Marx, 1990: 436-437).

In Democratic Kampuchea there were obviously no capitalists, no wages, and no private property. There was however the calculated administration of food rations as a means of garnering additional surpluses. What we wish to consider, therefore, is the idea that the 'food ration' contains its own, internal contradictions, for the food ration as constituted by the CPK entailed both a 'use-value' and 'exchange-value'. On the one hand, food rations marked the CPK's attempt to 'make life' in an immediate sense; a supposed guarantee of equal access on an individual basis to one of life's basic necessities: food. On the other hand, the imposition of food rations was an attempt to 'make life' for society as a whole, given that agricultural surpluses would be used to acquire other necessities for the Party and the revolution. To satisfy these two conditions, the CPK proposed that from 1977 onwards, the ration would be, in principle, $850 \mathrm{~g}$ of rice per person per year throughout the country (Party Center, 1976b: 51). Stated differently, the CPK calculated an amount of rice based on the socially necessary labor time required to plant and harvest rice.

The specific allocation of food rations warrants attention, for it provides a quantitative insight into the qualitative distinctions made by the CPK. Specifically, a four-fold system was devised to distribute food rations based on type of work-force. Those workers classified in the No. 1 system (robob) would be allocated three cans of rice per day; those in the No. 2 system, two-and-one-half cans; No. 3, two cans, and No. 4, one-and-one-half cans; for the CPK, cans used were usually Nestle's condensed milk cans. This numeric system refers to the type of labor involved; those people performing the heaviest manual labor, in principle, were to receive the highest rations. The lightest tasks, performed by the elderly or the sick, received the smallest rations. Pregnant women, or women who had just given birth, were at times given higher rations. Ostensibly, two side dishes (either soup or dried food) were to be provided to all workers; desserts were to be offered once every three days. Moreover, detailed work-schedules were devised-although not necessarily implemented-that determined how many days of work were required. In this way, the CPK determined the average amount of surplus that could be produced for the country as a whole.

Under the CPK, socially necessary labor times were also devised for particular administrative groupings of people; these aligned imperfectly with the aforementioned work-forces. Most prominent was the separation between 'base' people and 'new' people. 'Base' people, also known as 'old' people, were those who either participated in the revolution and/or lived in geographic zones controlled by the Khmer Rouge during the war. 'New' people (also identified as '17 April' people) consisted of those men and women who were evacuated from the cities and towns following the Khmer Rouge victory. Rhetoric of equality notwithstanding, these designations could literally mean the difference between life and death. 'Base' people, for example, were eligible for 'full rights', meaning that they were allowed to vote and run for elections. They could become chiefs of cooperatives and generally had access to better food rations and medical care. 'New' people, conversely, received less food, were treated more harshly, had fewer rights, and were directly killed more readily than 'old' people (Hinton, 2005: 86).

For each administrative zone separate calculations were also computed to determine the balance between surplus production and food rations. In the Western Zone, for example, a senior Party official-most likely Pol Pot-explained how such calculations would be determined:

If the Zone has 600,000 people, they must eat 150,000 tons of [rice]. But we want more than this in order to locate much additional oil, to get ever more rice mills, threshing machines, water pumps, and means of transportation, both as an auxiliary manual force and to give strength to our forces of production. So we must not get just 150,000 tons of [rice]. We must get $300,000,400,000,500,000$ tons just to break even and be able to build socialism ... (Party Center, 1976a: 20; see also Party Center, 1976b: Table 60).

Administrative calculations of food rations for each Zone, in turn, were aggregated to establish national quotas, forming the cornerstone of the CPK's overall economic policy. As detailed in the Party's Four-Year Plan, a target of 5.5 million tons of rice was established for 1977 for the entire country with each Zone responsible for a set proportion. By extension, the CPK determined that an equivalency of 3.2 million tons was required to be expended as capital (e.g. food rations, seeds, and 'welfare'). Of the estimated 2.3 million tons of 'surplus' rice, 1.3 million tons was to be exported; it is unclear as to distribution of the remaining one million tons. Based on an exchange rate of US\$200 per ton of rice, the CPK concluded that they would earn-in 1977-over US\$277 million. Subsequently, a ratio of 7:3 was established, whereby 70 percent of surplus was to be spent for the 'base' in order to build the zones, regions, and other units, while the remaining 30 percent was set aside for the state to defend and build the country. Lastly, separate calculations were determined to allocate the distribution of expenditures, categorized by national reconstruction, defense of bases, and livelihood.

Other practices were initiated that enforced reliance upon government-calculated food rations. The abolition of private property, for example, precluded the ability of people from supplementing their diets beyond the government-imposed rations. Official CPK policy forbade private cooking or eating, stating that everything in the country was the property of the revolution and could not be taken without permission (DeFalco, 2013b: 30). 
Consequently, all fruits, vegetables, and animals found in the wild belonged to the Party; one risked imprisonment, torture, or execution for simply taking a fish from a pond or a coconut from a tree (DeFalco, 2013a: 31). Likewise, throughout 1976 and 1977 communal eating was imposed throughout the co-operatives. This practice served a variety of functions. On the one hand, collective dining was a means of ensuring discipline and loyalty to the Party. On the other hand, communal eating facilitated the distribution and consumption of food; this was a crucial element for those cadres responsible for providing set amounts of surplus to the party. Indeed, it was not uncommon for co-operative chiefs, acting out of either fear or an eagerness to please the Party Center, often prioritized meeting the quota over feeding the people (Bashi, 2008). For many Cambodians, consequently, the average ration was far less than that proposed in official documents; in practice, rations frequently consisted of just two small ladles of watery rice or corn gruel per day (Dy, 2007: 29-30).

Beyond the control afforded by communal eating, CPK officials actively monitored agricultural and food rationing throughout Democratic Kampuchea (DeFalco, 2011: 150). Shortly after taking power, for example, the CPK established a national system of reporting, whereby local Khmer Rouge officials were required to send telegrams to the central office in Phnom Penh; such administrative reporting was to include updates on a range of topics, including agricultural productivity and security problems (DeFalco, 2013b: 31). On March 30, 1976 members of the CPK Central Committee ordered that a system of weekly reports on agricultural productivity be established; this would ensure that the 'Center' could "plan" and "resolve problems in a timely fashion" toward the goal of increasing rice production of three tons per hectare (Party Center, 1976c: 3).

The food rationing and regulation system under the CPK bears a stark resemblance to the contemporary North Korean Public Distribution System (PDS). Under the PDS, the government of North Korea uses a similar classification strategy to distribute food based on occupation and age group (Noland, 2007). Children, college students, members of the military, office workers, and heavy laborers - among other classifications - receive different daily amounts of grain, with higher amounts reserved for government officials, special security, and the military. During the 1990s as agricultural productivity collapsed, PDS rations were frequently cut for the most vulnerable groups while the deepest cuts were enacted in politically restive districts. When these adjustments failed to meet the increasing food gap, the government resorted to seizing grain from rural households. These adjustments - alongside bans on hunting, foraging, migration, and informal markets - were enacted to preserve grain for Pyongyang and the political elite at the expense of rural laborers, a clear case of taking life to make life. The resulting famine during the 1990s claimed an estimated 3-5 percent of the North Korean population. (For a detailed analysis of the PDS, see Noland \& Haggard, 2007.)

\section{How the Khmer Rouge produced vulnerability}

Returning to Bohle's three modes of inquiry, we can now understand how the policies under the Khmer Rouge produced vulnerability to mass starvation and disease.

\section{Human ecology and the Nature-society relationship}

Through the forced displacement of the population, the CPK dramatically altered the human environment both for urban and rural inhabitants. The collective movement of people from diverse parts of the country into agricultural communes exposed people to infectious diseases, while the close confines, unsanitary living conditions, and rudimentary medical care present in the communes accelerated the spread of such diseases-conditions of which the CPK leadership was aware (OCIJ, 2010). This pattern of displacement and confinement, and its attendant mortality, is one of two common features of the famine-disease cycle. In most historical instances, victims leave a famine zone seeking shelter at overcrowded refugee camps. These camps become the breeding grounds for dysentery, cholera, typhus, and other diseases (De Waal, 2004). In most cases, deaths from disease outnumber and outlast deaths from starvation (Fraser, 2007). David Arnold examines this "synergistic relationship" (1993: 385) between disease and migration in the case of the Madras famine of 1876-78. He argues that these social adaptations to the collapse of food provisioning led to dysfunctional behaviors - like migration and the consumption of famine foods - that ultimately exposed victims to disease. Though the outcome was similar in this case, the cause differed: in the early days of Democratic Kampuchea, the mass migration of people was not a dysfunctional adaptation motivated by the sharp pangs of hunger but by the sharp bayonets of the CPK.

The second feature of the famine-disease cycle is the effect of reduced nutritional intake on the human body. Poor nutrition weakens immune systems and exposes them to ordinarily innocuous infections (Fraser, 2007). Under the Khmer Rouge, poor nutrition was a combination of calculated decisions: unrealistic national rice quotas, the implementation of food rations, and the desire (or fear) of administrators to please (or not please) the Party with assurances that quotas were being met.

Malaria was one of the most pernicious diseases to afflict Cambodians during this period. Though mortality figures are unavailable, a UNICEF and International Red Cross report published in 1979 reported that approximately half of the people living in the highland strongholds of the Khmer Rouge suffered from malaria (Meng-Try, 1981). Migration has been identified as a causal factor in both historical famines (Arnold, 1993) and in the spread of malaria today (see Martens \& Hall, 2000). Not only does migration bring infected people into contact with potential victims, population movement can lead to environmental changes that create favorable habitats for Anopheles mosquitos, for example, deforestation and the construction of irrigation systems. In Democratic Kampuchea, the spike in malaria may be largely attributed to the movement of so many people without immune resistance into cleared forests inundated for rice production, a problem still facing the Cambodian population today (Chatterjee, 2005).

\section{Expanded entitlements}

Through the appropriation of all food and the prohibition of fishing, hunting and gathering, the Khmer Rouge transformed the structure of entitlements and resource endowments. The elimination of currency further enforced the end of old patterns of entitlement exchange. Even if moral economies and social networks of exchange had been allowed to persist, the displacement and confinement of the population into the CPK's new, vertically organized space-economy effectively destroyed such networks. This was a calculated erasure: old systems of land, labor and resource allocation - indeed, every pre-existing form of entitlement to food - had to be eliminated before the new system could be inscribed. Absolute control over rice consumption was necessary to guarantee that quotas for the surplus could be calculated and achieved.

The new entitlement system revolved around the allocation of rations. 'Base' people had access to power (through the ability to run for elections and become chiefs of cooperatives) and thus enjoyed improved access to food, while 'new' people received less food and were generally treated more harshly. At the same time, 
workers were classified into four levels of rationing based on the demands of the work being performed. This entailed that the most physically able workers received the most rice per day, while the old and infirm received the least. This change radically altered the distribution of 'winners' and 'losers.' For the losers, the result was a sudden increase in exposure to harm and a decrease in capacity to survive the consequences.

It is here that a comparison can be drawn with the Irish famine of 1845-1850. In his analysis of the Irish Poor Law system, Nally (2008) finds that the crisis provided the opportunity for the state to intervene between the population and their food supply, exploiting the catastrophe "to further the aims of population reform," and justifying the view that "agricultural rationalization, fiscal restructuring, and population clearances were necessary to 'ameliorate' and 'improve' Irish society" (2008: 714). As with Cambodia, the replacement of existing endowments and entitlements with state-mediated ones enabled the state to make "dangerous distinctions between productive and unproductive life" (2008: 714); indeed, to make life through letting die.

\section{Political economy}

The Khmer Rouge wanted to create a state funded by rice exports, a policy that justified the pursuit of an ever-expanding surplus. To increase overall production, the Khmer Rouge sought to (1) increase the area under cultivation, (2) increase the overall productivity of agriculture, and (3) limit domestic rice consumption. To increase cultivated area, labor was required to build paddy, irrigation works, and cultivate new fields. This work was supplied in the form of forced labor. The plan to increase productivity involved the domestic production or importation of agricultural tools, fertilizers, pesticides, and herbicides. To produce these agricultural inputs domestically entailed additional forced labor, while importation depended once again on the rice surplus (and, by extension, forced labor). Finally, to reduce domestic rice consumption, the Khmer Rouge imposed a rationing system on the workforce.

In these ways, the new political economy of Democratic Kampuchea placed the majority of the population between the teeth of two powerful forces: a demand for surplus rice and agricultural inputs that justified draconian labor policies, and a rationing system that winnowed away every excess grain of rice. For workers, the result was an institutional arrangement which could not (and would not) respond to the developing famine in a manner benefiting recovery. As we will see, it was an arrangement that responded to the growing crisis with even greater brutality.

Through each mode of inquiry we find the actions and policies of the Khmer Rouge producing vulnerability-ironically, though, from the standpoint of attempting to 'make live'. Simply put, CPK introduced specific policies in an attempt to more effectively harness the resources of Democratic Kampuchea; in the process, however, the CPK was willing to let die large numbers of its citizens.

Here we return to the question of intentionality. DeFalco suggests that the policies forwarded by the CPK may have been "unrealistic" and predicated upon "incorrect assumptions" (2013a: 31). We contend that these policies must be recognized and understood as rational administrative decisions calculated and executed with full knowledge of the consequences (cf. OCIJ, 2010). To suggest otherwise is to argue either that the CPK did not maintain complete administrative oversight over agriculture, or that the CPK was unaware of the fatal conditions that resulted from these policies. As to the former, the extensive records of rice production, the geographically-specific decisions made for each district and subdistrict, and the system of weekly reports from all rice-producing areas, argues convincingly for a government in complete control. As to the latter, DeFalco himself concludes that the evidence "strongly suggests that the upper echelons of the CPK government expropriated and exported mass quantities of rice throughout the DK period with clear knowledge that this rice was coming at the expense of civilians" (2011: 151-152). In a speech delivered on April 17, 1978, marking the third anniversary of the Khmer Rouge victory, Khieu Samphan, President of the Presidium of the State of Democratic Kampuchea, announced that the CPK "decided to export more rice than the previous year so that [Democratic Kampuchea] can accumulate more capital for national construction" (Document No. D21934, Documentation Center of Cambodia, Phnom Penh).

Likewise, other documentary evidence reveals that top members of the CPK were aware of these conditions yet pursued different courses of action. In meeting minutes from 8 March 1976, cadre acknowledged "the problems of many sick people in the work sites, a loss of 40 percent of the labor force" and yet conclude that "expenditures for material purchases to solve the livelihood of the people are limited because we must purchase many other things as well." In the end, the committee reiterated the two can per day food ration (Document No. D00684, Documentation Center of Cambodioa, Phnom Penh). The solution to the problem was greater 'revolutionary zeal' among the workers and those cadre not meeting expectations were, by the CPK's definition, traitors to both the state and the revolution (see for example Document Nos. D00707 and D02166, Documentation Center of Cambodia, Phnom Penh).

\section{The Co-Production of direct and structural violence}

Taken as a whole, the policies and practices associated with generating both absolute and relative agricultural surpluses - the same practices that produced vulnerability - may be seen as creating specific structures of violence. To these we must add the imposition of law-preserving practices designed to enforce the surpluses. Foremost of these practices was the establishment of a nation-wide security apparatus tasked with countering dissent and fabricating a discourse of internal 'enemies.' While Pol Pot made statements of abundance, the Santebal (secret police) "arrested, tortured, sometimes executed those who complained about lack of food" (DeFalco, 2011: 151). Surviving CPK documents describe people being arrested for 'stealing' food or merely complaining about insufficient rations (DeFalco, 2013b, 30). Such punishment was not confined to the masses: CPK leaders purged local officials who admitted that starvation was occurring in their areas (DeFalco, 2013b: 31). As the food crisis increased, the CPK blamed traitorous and inept low-level cadres of undermining the food production system (DeFalco, 2011). This discourse-coupled with longstanding animosity and distrust of the Vietnamese (Kiernan, 2008) created the perception of internal enemies, justifying the CPK's intensification of surveillance, imprisonment, and execution of supposed traitors. In biopower terms, these relations of enmity that constructed threats within and without, reinforced the CPK's state of exception and the normative imposition of the ration (see Mbembe, 2003: 16).

To support the security apparatus, one of the most crucial imports purchased with the rice surplus was weapons. (Noland and Haggard (2007) offer a contemporary example of this militarization-throughstarvation approach in the case of North Korea.) Following a policy of agriculture-driven industrial development, the CPK needed surplus production to satisfy the state's immediate need for the build-up of industry and-increasingly — national security. According to Kiernan (2008: 132-134, 378), the CPK traded rice and other foodstuffs for military weaponry, including coastal patrol vessels, tanks, and artillery; by late 1976 large weapons shipments of tanks, armored personnel carriers, and even guns began to arrive. The imposition of starvation rations was crucial. In a further dark irony, those exported 
grains of rice that could have nourished Cambodian lives may have returned to the country as some of the very bullets used to take those lives. Not only did the structural policies of rationing and export create vulnerability to death and a discourse that justified executions and purges, they provided the material basis for mass murder through the expansion of the CPK's security apparatus.

These cases demonstrate how direct violence and structures of violence in Democratic Kampuchea were mutually constitutive, illuminating the dialectical relationship between these traditional binaries. Without the threat of direct violence, the policies of rationing and surplus could not have been enforced. Without the policies of rationing and surplus, neither the material nor discursive basis for direct violence could have been realized. The intentional and direct taking of life was dependent on, and integral to, the disallowal of life explicit in the forced ration. Simultaneously, the ration and rice surplus was dependent on, and integral to, the direct taking of life through execution and imprisonment, actual and threatened. Thus, the administrative violence brought to bear on Cambodians in the crucible of fear and starvation was not simply law-making or simply law-preserving: it was both.

\section{Conclusions}

If we conceive of violence as any action or inaction that affects the material and non-material conditions of another, thereby reducing one's potential to survive, we are better positioned to re-articulate the practices of the Communist Party of Kampuchea as criminal. In this paper we consider the agricultural policies forwarded by the CPK as a form of administrative violence, and argue that the CPK's mass taking of life was integral to the attempt to make life. We argue that the policy of forced rations - in which this contradiction is embodied - was a key part of the calculated management of life and death, and as such, we propose that the deaths from exposure, starvation, and disease were not unintended side effects of poor research, poor planning, or poor implementation, but rather the necessary consequence of the CPK's distinct imperative to increase surplus.

To make this claim (and conceive of violence in this way) challenges the traditional dichotomy between direct and structural violence. It also brings into question the moral partition between killing and letting die. This moral partition is based on intentionality, with intentional acts judged to be "worse" than unintended ones. However, when we recast structural violence as a form of letting die, we find that the leaders of the CPK were (1) aware of harmful policies and practices, (2) had the opportunity to stop and provide remedy, and (3) had the political and material capability to prevent harm. The CPK's awareness, opportunity, and capacity suggest that deaths resulting from agricultural policy be treated with the same moral potency as killing.

To show how the CPK's policies led to death we employed the concept of vulnerability. Through three modes of inquiry we found the policies of the CPK actively produced vulnerability; that is, increased the risk of exposure to crisis, reduced each person's capacity to adapt, and increased the chance of serious harm. Through displacement, re-confinement, forced rationing, and other deprivations, the CPK negatively affected the material conditions of the population and reduced their potential to survive. We compared these policies and outcomes with other famine events in India, North Korea, and Ireland, finding evidence that both the intentionality and efficacy of CPK policies fit into broader historical themes of making life through death.

We conclude that these tactics of social reorganization established a structure of violence that - in concert with the direct violence of imprisonment and execution - led to the deaths of 2 million people. This systematic co-production of violence (through technologies like the ration, the reorganized space-economy, and the draconian security apparatus) subjugated life to the threat of death, an expression of what Mbembe terms necropower: "the generalized instrumentalization of human existence and the material destruction of human bodies and populations" (2003:14). The CPK implemented these policies not out of insanity or impulsive cruelty, but because such policies were rational to the imperatives of state capitalism.

\section{Conflict of interest statement}

We have no conflict of interest in this submission.

\section{Acknowledgments}

The authors thank Simon Springer, Philippe Le Billon, and three anonymous reviewers for insightful comments and feedback on earlier drafts. Thanks are also extended to the staff at the Documentation Center of Cambodia.This research was supported by a grant (\#1262736) from the National Science Foundation. Omissions and shortcomings are our own.

\section{References}

Anglin, M. K. (1998). Feminist perspectives on structural violence. Identities, 5(2), 145-151.

Arnold, D. (1993). Social crisis and epidemic disease in the famines of nineteenthcentury India. Social History of Medicine, 6(3), 385-404.

Beaugrand, C. (2011). Stateless \& administrative violence: Bidūns' survival strategies in Kuwait. The Muslim World, 101(2), 228-250.

Benjaminm, W. (1921). Critique of violence. In P. Demetz (Ed.), Reflections: essays, aphorisms, autobiographical writings 1978 (pp. 277-300). New York: Schocken Books.

Bohle, H. G., Downing, T. E., \& Watts, M. J. (1994). Climate change and social vulnerability: toward a sociology and geography of food insecurity. Global Environmental Change, 4(1), 37-48.

Brown, M. M. (1985). Famine. A man-made disaster. A report for the independent commission on international humanitarian issues. New York, New York: Vintage Special Books.

Chandler, D., Kiernan, B., \& Boua, C. (Eds.). (1988). Pol pot plans the future: Confidential leadership documents from democratic Kampuchea, 1976-1977. New Haven, CT: Yale University Press.

Chatterjee, P. (2005). Cambodia's fight against malaria. The Lancet, 366(9481), $191-192$.

Confortini, C. (2006). Galtung, violence, and gender: the case for a peace studies/ feminism alliance. Peace and Change, 31(3), 333-367.

De Waal, A. (2004). Famine that kills: Darfur, Sudan. Oxford, UK: Oxford University Press.

DeFalco, R. C. (2011). Accounting for famine at the extraordinary chambers in the courts of Cambodia: the crimes against humanity of extermination, inhumane acts and persecution. The International Journal of Transitional Justice, 5(1), $142-158$.

DeFalco, R. C. (2013a). Voices of genocide: Justice and the Khmer Rouge famine. In Searching for the Truth, First Quarter, 2013 pp. 29-32).

DeFalco, R. C. (2013b). Voices of genocide: Episodes of the radio program on famine under the Khmer Rouge. In Searching for the Truth, Second Quarter, 2013 pp. 26-32).

Dreze, J., \& Sen, A. (1991). Hunger and public action. Oxford, UK: Claredon.

Dy, K. (2007). A history of Democratic Kampuchea (1975-1979). Phnom Penh, Cambodia: Documentation Center of Cambodia.

Edgerton-Tarpley, K. (2008). Tears from Iron: Cultural responses to famine in Nineteenth-Century China. Berkeley, CA: University of California Press.

Edkins, J. (2000). Whose hunger? Concepts of famine, practices of Aid. Minneapolis, MN: University of Minnesota Press.

Edkins, J. (2002). Mass starvations and the limitations of famine theorizing. IDS Bulletin, 33(4), 12-18.

Edkins, J. (2007). The criminalization of mass starvations: from natural disaster to crime against humanity. In S. Devereux (Ed.), The new famines. New York, NY: Routledge.

Essex, J. (2009). The work of hunger: security, development, and food-for-work in post-crisis Jakarta. Studies in Social Justice, 3(1), 99-116.

Essex, J. (2012). Idle hands are the devil's tools: the geopolitics and geoeconomics of hunger. Annals of the Association of American Geographers, 102(1), 191-207.

Fine, B., \& Saad-Filho, A. (2010). Marx's capital (5th ed.). New York, NY: Pluto Books. Franke, R. W., \& Chasin, B. H. (1980). Seeds of Famine: Ecological destruction and the development dilemma in the West African Sahel. Boulder, CO: Rowman \& Littlefield. 
Fraser, E. D. G. (2007). Travelling in antique lands: using past famines to develop an adaptability/resilience framework to identify food systems vulnerable to climate change. Climatic Change, 83(4), 495-514.

Galtung, J. (1969). Violence, peace, and peace research. Journal of Peace Research, 6(3), 167-191.

Graeber, D. (2012). Dead zones of the imagination: on violence, bureaucracy, and interpretive labor. HAU: Journal of Ethnographic Theory, 2(2), 105-128.

Green, O. H. (1980). Killing and letting die. American Philosophical Quarterly, 17(3), $195-204$.

Gunneflo, M. (2012). The targeted killing judgment of the Israeli Supreme Court and the critique of legal violence. Law Critique, 23(1), 67-82.

Gupta, A. (2012). Red tape: Bureaucracy, structural violence, and poverty in India. Durham, NC: Duke University Press.

Heuveline, P. (1998). 'Between one and three million': towards the demographic reconstruction of a decade of Cambodian history. Population Studies, 52(1), 49-65.

Hinton, A. L. (2005). Why did they kill? Cambodia in the shadow of genocide. Berkeley, CA: University of California Press.

Hionidou, V. (2006). Famine and death in occupied Greece, 1941-1944. Cambridge: Cambridge University Press.

Hume, M. (2008). The myths of violence: gender, conflict, and community in El Salvador. Latin American Perspectives, 162(5), 59-76.

Keen, D. (1994). The benefits of famine: A political economy of famine and relief in Southwestern Sudan, 1983-1989. Princeton: Princeton University Press.

Kiernan, B. (2003). The demography of genocide in Southeast Asia: the death tolls in Cambodia, 1975-1979, and East Timor, 1975-1980. Critical Asian Studies, 35(4), 585-597.

Kiernan, B. (2008). The Pol Pot regime: Race, power, and genocide in Cambodia under the Khmer Rouge, 1975-79 (3rd ed.). New Haven, CT: Yale University Press.

Li, T. M. (2009). To make life or let die? Rural dispossession and the protection of surplus populations. Antipode, 41(1), 66-93.

Loyd, J. (2009). 'A microscopic insurgent': militarization, health, and critical geographies of violence. Annals of the Association of American Geographers, 99(5), $863-873$.

Loyd, J. (2012). Geographies of peace and antiviolence. Geography Compass, 6(8), $477-489$.

Malthus, T., \& Gilbert, G. (1993). An essay on the principle of population. UK: Oxford University Press.

Martens, P., \& Hall, L. (2000). Malaria on the move: human population movement and malaria Transmission. Infectious Diseases, 6(2), 103-109.

Marx, K. (1990). Capital: A critique of political economy, volume 1. New York, NY: Penguin Books.

Mbembé, J. A., \& Meintjes, L. (2003). Necropolitics. Public Culture, 1(1), 11-40.

Meillassoux, C. (1974). Development or exploitation: is the Sahel famine good business? Review of African Political Economy, 1(1), 27-33.

Meng-Try, E. A. (1981). Kampuchea: a country adrift. Population and Development Review, 7(2), 209-228.

Nally, D. P. (2008). "That coming Storm": the Irish Poor Law, colonial Biopolitics, and the great famine. Annals of the Association of American Geographers, 98(3), $714-741$.

Nally, D. P. (2011). Human Encumbrances: Political violence and the Great Irish famine. South Bend, IN: University of Notre Dame Press.

Noland, M. (2007). North Korea as a 'new' famine. In S. Devereux (Ed.), The new famines. New York: Routledge.

Noland, M., \& Haggard, S. (2007). Famine in North Korea: Markets, aid, and reform (pp. 197-221). New York, NY: Columbia University Press.

Office of the Co-Investigation Judges (OCIJ). (2010). Closing Order: Case File No. 002/ 19-04-2007-ECCC-OCIJ. Phnom Penh, Cambodia: Extraordinary Chambers in the Courts of Cambodia.
Ollman, B. (2003). Dance of the dialectic: Steps in Marx's Method. Urban-Champaign, IL: University of Illinois Press.

Party Center of the Communist Party of Kampuchea. (1976a [1988]). Preliminary explanation before reading the plan, by the Party Secretary. In D. Chandler, B. Kiernan, \& C. Boua (Eds.), Pol pot plans the future: Confidential leadership documents from Democratic Kampuchea 1976-1977 (pp. 119-163). New Haven CT: Yale University Press.

Party Center of the Communist Party of Kampuchea. (1976b [1988]). The Party's four-year plan to build socialism in all gields, 1977-1980. In D. Chandler, B. Kiernan, \& C. Boua (Eds.), Pol Pot plans the future: Confidential leadership documents from Democratic Kampuchea 1976-1977 (pp. 36-118). New Haven CT: Yale University Press.

Party Center of the Communist Party of Kampuchea. (1976c [1988]). Decisions of the Central Committee on a variety of questions. In D. Chandler, B. Kiernan, \& C. Boua (Eds.), Pol pot plans the future: Confidential leadership documents from Democratic Kampuchea 1976-1977 (pp. 1-8). New Haven CT: Yale University Press.

Postone, M. (1993). Time, labor, and social domination: A reinterpretation of Marx's critical theory. Cambridge UK: Cambridge University Press.

Rangasami, A. (1985). Failure of exchange entitlements' theory of famine: a response. Economic and Political Weekly, 20(1747-1752), 1797-1801.

Sen, A. (1981). Poverty and famines: An essay on entitlements and deprivation. Oxford, UK: Clarendon Press.

Spade, D. (2011). Normal life: Administrative violence, critical trans politics, and the limits of law. Brooklyn, NY: South End Press.

Springer, S. (2008). The nonillusory effects of neoliberalization: Linking geographies of poverty, inequality, and violence. Geoforum, 39(4), 1520-1525.

Springer, S. (2009). Violence, democracy, and the neoliberal 'order': the contestation of public space in posttransitional Cambodia. Annals of the Association of American Geographers, 99(1), 138-162.

Springer, S. (2011). Violence sits in places? Cultural practice, neoliberal rationalism, and virulent imaginative geographies. Political Geography, 30(2), 90-98.

Springer, S. (2012). Neoliberalising violence: of the exceptional and the exemplary in coalescing moments. Area, 44(2), 136-143.

Tyner, J. A. (2008). The Killing of Cambodia: Geography, genocide and the unmaking of space. Aldershot, UK: Ashgate.

Tyner, J. A. (2009). War, violence, and population: Making the body count. New York, NY: The Guilford Press.

Tyner, J. A. (2012a). Space, place, and violence: Violence and the embodied geographies of race, sex, and gender. New York, NY: Routledge.

Tyner, J. A. (2012b). State sovereignty, bioethics, and political geographies: the practice of medicine under the Khmer Rouge. Environment and Planning D: Society and Space, 30(5), 842-860.

Tyner, J. A. (2014a). Dead labor, homo sacer, and letting die in the labor market. Human Geography, 7(1), 35-48.

Tyner, J. A. (March 2014b). Dead labor, mass graves, and landscapes: administrative violence during the Cambodian genocide. Geoforum, 52, 70-77.

Tyner, J. A., \& Inwood, J. (2014). Violence as fetish: geography, Marxism and dialectics. Progress in Human Geography, 38(6), 771-784.

Watts, M. (1991). Entitlements or empowerment? Famine and starvation in Africa. Review of African Political Economy, 18(51), 9-26.

Watts, M. (2013). Silent Violence: Food, famine, and Peasantry in Northern Nigeria. Athens: University of Georgia Press.

Watts, M. J., \& Bohle, H. G. (1993). The space of vulnerability: the causal structure of hunger and famine. Progress in Human Geography, 17(1), 43-67.

Woo-Cumings, M. (2002). The political ecology of famine: The North Korean catastrophe and its lessons. Manila, Philippines: Asian Development Bank Institute. No. 31. 